\title{
Correction to: Gliosarcoma vs. glioblastoma: a retrospective case series using molecular profiling
}

\author{
Christopher Dardis $^{1 *}$, David Donner², Nader Sanai ${ }^{3}$, Joanne Xiu ${ }^{4}$, Sandeep Mittal ${ }^{5}$, Sharon K. Michelhaugh" \\ Manjari Pandey ${ }^{6}$, Santosh Kesari ${ }^{7}$, Amy B. Heimberger ${ }^{8}$, Zoran Gatalica ${ }^{9}$, Michael W. Korn ${ }^{4}$, \\ Ashley L. Sumrall ${ }^{10}$ and Surasak Phuphanich ${ }^{11}$
}

\section{Correction to: BMC Neurol 21, 231 (2021) \\ https://doi.org/10.1186/s12883-021-02233-5}

Following publication of the original article [1], the authors reported an error that the wrong version of the Additional file 2 was published. The correction version of Additional file 2 is now updated.

The original article [1] has been updated.

\section{Supplementary Information}

The online version contains supplementary material available at https://doi. org/10.1186/s12883-021-02326-1.

Additional file 2. This is the statistical analysis, provided in .pdf format. This contains the $\mathrm{R}$ code used in the analysis and so parts of this are likely to be hard to understand for the reader not familiar with this language. The file provides the results given in the main article. It includes some additional analyses and images which, for reasons of space, do not form part of the main article. In particular, it provides details of all of the MTs assessed. For each gene assessed, we also provide hyperlinks (where possible), to the relevant entry at the NCBI Gene database (https://www.ncbi. nlm.nih.gov/gene).

\begin{abstract}
Author details
${ }^{1}$ Department of Neurology, Barrow Neurological Institute, Phoenix, AZ, USA. ${ }^{2}$ School of Medicine, Creighton University, Phoenix, AZ, USA. ${ }^{3}$ Barrow Brain Tumor Research Center, Department of Neurosurgery, Barrow Neurological Institute, Phoenix, AZ, USA. ${ }^{4}$ Precision Oncology Alliance, Caris Life Sciences, Phoenix, AZ, USA. ${ }^{5}$ Fralin Biomedical Research Institute, Virginia Tech Carilion School of Medicine, Roanoke, VA, USA. ${ }^{6}$ Department of Medical Oncology, West Cancer Center, University of Tennessee Health Science Center, Germantown, TN, USA. ${ }^{7}$ Pacific Neuroscience Institute and Department of Translational Neurosciences and Neurotherapeutics, John Wayne Cancer Institute, Santa Monica, CA, USA. ${ }^{8}$ Simpson Querry Biomedical Research Center, Department of Neurosurgery, Feinberg School of Medicine, Northwestern University, Chicago, IL, USA. ${ }^{9}$ Department of Pathology, University of Oklahoma Health Sciences Center, Oklahoma City, OK, USA. ${ }^{10}$ Department of Medical Oncology, Levine Cancer Institute, Atrium Health, Charlotte, NC, USA. " ${ }^{11}$ Department of Medicine, Samuel Oschin Comprehensive Cancer Institute, Cedars-Sinai Medical Center, Los Angeles, CA, USA.
\end{abstract}

Published online: 14 August 2021

\section{Reference}

1. Dardis C, Donner D, Sanai N, et al. Gliosarcoma vs. glioblastoma: a retrospective case series using molecular profiling. BMC Neurol. 2021;21:231. https://doi.org/10.1186/s12883-021-02233-5.

\section{Publisher's Note}

Springer Nature remains neutral with regard to jurisdictional claims in published maps and institutional affiliations.

The original article can be found online at https://doi.org/10.1186/s12883021-02233-5.

\footnotetext{
*Correspondence: christopherdardis@gmail.com

1 Department of Neurology, Barrow Neurological Institute, Phoenix, AZ, USA

Full list of author information is available at the end of the article
} original author(s) and the source, provide a link to the Creative Commons licence, and indicate if changes were made. The images or other third party material in this article are included in the article's Creative Commons licence, unless indicated otherwise in a credit line to the material. If material is not included in the article's Creative Commons licence and your intended use is not permitted by statutory regulation or exceeds the permitted use, you will need to obtain permission directly from the copyright holder. To view a copy of this licence, visit http://creativecommons.org/licenses/by/4.0/. The Creative Commons Public Domain Dedication waiver (http://creativeco mmons.org/publicdomain/zero/1.0/) applies to the data made available in this article, unless otherwise stated in a credit line to the data. 